DOI: $10.15193 /$ zntj/2019/119/283

\author{
WOJCIECH SAWICKI, ARKADIUSZ ŻYCH
}

\title{
METODA PCR W OCENIE ZAFALSZOWAŃ SKLADU SUROWCOWEGO PRODUKTÓW MIĘSNYCH ZE STRUSIA (STRUTHIO CAMELUS)
}

\begin{abstract}
Streszczenie
Poprawne znakowanie mięsa pozwalające konsumentowi świadomie wybrać jego rodzaj jest istotne z wielu względów - od zdrowotnych po religijne. Ponadto ze względu na różnice cen i dostępność surowców mięsnych pochodzących z różnych gatunków zwierząt zdarzają się przypadki fałszowania żywności. Składniki wyrobów mięsnych są wykorzystywane nieadekwatnie do informacji podanej na etykiecie. Niezgodności dotyczą zarówno użytych surowców, jak i ich zawartości w produkcie mięsnym. Mięso o wysokiej jakości zastępuje się tańszym lub jego zawartość jest mniejsza od deklarowanej. Choć obowiązują przepisy dotyczące znakowania przetworzonych produktów mięsnych, zdarzają się przypadki występowania na rynku wyrobów mięsnych zafałszowanych. W niniejszych badaniach podjęto się opracowania procedury weryfikacji autentyczności wyrobów z mięsa strusia czerwonoskórego (Struthio camelus). Zaproponowano metodę wykorzystującą technikę real-time PCR. Jak wykazano, DNA jest wystarczająco stabilne, aby wytrzymać zróżnicowaną obróbkę technologiczną. Badania prowadzono z użyciem wyrobów modelowych oraz wyrobów mięsnych (kiełbas, steków, mięsa gulaszowego) zakupionych w handlu detalicznym. Próbki były analizowane pod względem obecności niedeklarowanych gatunków mięsa (wieprzowiny, wołowiny, mięsa z kurcząt, kaczek i gęsi) z wykorzystaniem gatunkowo specyficznych starterów. Na podstawie otrzymanych wyników wykazano, że opracowana procedura identyfikacji mięsa strusia może być $\mathrm{z}$ powodzeniem stosowana $\mathrm{w}$ rutynowych kontrolach, zarówno jakościowych (wykluczenie danego gatunku), jak i ilościowych (oznaczenie udziału mięsa strusia) w tego typu żywności. Wykazano ponadto, że w wyrobach przetworzonych może występować problem niedeklarowanego dodatku mięsa innego niż wskazane na etykiecie.
\end{abstract}

Słowa kluczowe: mięso strusia, identyfikacja, zafałszowania żywności, real-time PCR

\section{Wprowadzenie}

Produkty drobiowe można uznać za jedno z najważniejszych źródeł białka. Jest ono zdecydowanie tańsze od mięsa czerwonego, co wpływa na zauważalny wzrost jego

Dr inż. W. Sawicki, Zakład Mikrobiologii i Biotechnologii Stosowanej, Wydz. Nauk o Żywności i Rybactwa, Zachodniopomorski Uniwersytet Technologiczny w Szczecinie, ul. Papieża Pawła VI 3, 71-459 Szczecin, dr inż. A. Żych, Katedra Technologii Mięsa, Wydz. Nauk o Żywności i Rybactwa, Zachodniopomorski Uniwersytet Technologiczny w Szczecinie, ul. Kazimierza Królewicza 4, 71-550 Szczecin. Kontakt:wojciech.sawicki@zut.edu.pl 
konsumpcji, a tym samym na wzrost produkcji surowca drobiarskiego [9]. Oprócz niskiej ceny o wyborze drobiu przez konsumentów decydują również walory smakowe, kruchość czy soczystość. Ponadto wzrostowi popytu na surowiec drobiowy towarzyszy rozwój technologii jego przetwórstwa i bogactwo form kulinarnych [3]. Wykorzystywany w przetwórstwie drobiowym surowiec rzeźny to przede wszystkim kurczęta, kury, kaczki, indyki i gęsi, jednak coraz większe zainteresowanie wzbudza także mięso strusi $[16,20]$.

W wielu krajach, w tym w Polsce, od dłuższego czasu można zaobserwować wzrost zainteresowania chowem ptaków bezgrzebieniowych, w tym strusi, emu i nan$\mathrm{du}[15,16]$. Jest to spowodowane $\mathrm{z}$ jednej strony wysokimi wymaganiami wspólnego rynku, a z drugiej - trendem hodowli zwierząt egzotycznych, obserwowanym w całej Europie. Poza tym rolnicy zaczęli poszukiwać dodatkowych i alternatywnych źródeł dochodu i nowych sposobów wykorzystania zasobów gospodarstwa rolnego [4]. Strusie, przy zapewnieniu odpowiednich wybiegów i pomieszczeń na okres zimowy, bez większych kłopotów zaadaptowały się w naszym klimacie [2]. W Polsce powstały fermy, w których zaczęto chów strusi z przeznaczeniem na mięso. Strusie osiągają dojrzałość ubojową w wieku ok. 12 miesięcy, przy masie ciała ok. $90 \mathrm{~kg}$. Z jednej tuszy otrzymuje się $30 \div 35 \mathrm{~kg}$ mięsa (w tym ponad $20 \mathrm{~kg}$ w klasie I) o wysokich walorach smakowych i zdrowotnych, tj. niewielkiej kaloryczności i małej zawartości cholesterolu (60 mg/100 g tkanki) [5, 14]. Ponadto strusina zawiera stosunkowo niewiele tłuszczu $(1,2 \%)$, natomiast smakiem i strukturą najbardziej przypomina wołowinę. Pod względem delikatności, smakowitości i zapachu nie ustępuje najcenniejszym elementom tuszy wołowej, np. polędwicy [33].

Przez kilka ostatnich lat powstało wiele systemów umożliwiających śledzenie i identyfikację surowców i produktów pochodzenia zwierzęcego. Jednocześnie wciąż powszechnie podnoszone są zagadnienia niejasności i nieścisłości w stosowaniu warunków i procedur "identyfikacji", "śledzenia" i "weryfikacji" [22]. Najtrudniejszym problemem jest weryfikacja tożsamości gatunkowej mięsa. Przetwórstwo mięsa składa się z różnych etapów technologicznych, którym należałoby przypisać określone procedury kontrolne poświadczające jakość i bezpieczeństwo produktu w systemie "od pola do stołu" [24, 26, 32].

Różne metody i techniki zostały zaadaptowane do identyfikacji mięsa zwierząt rzeźnych. Na poziomie żywych zwierząt najczęściej są to paszporty, kolczyki, tatuaże, systemy RFID (czipy systemu identyfikacji radiowej), księgi rejestracji [7, 28, 30]. W przypadku nieprzestrzegania określonych zasad i procedur w procesie przetwórstwa mięsa może natomiast dojść do zamierzonego fałszowania lub niezamierzonego zanieczyszczenia produktu surowcem obcogatunkowym [7, 27]. Zatem wybór techniki identyfikacji gatunkowej mięsa i produktów mięsnych powinien zależeć od stopnia jego przetworzenia i zastosowanych procesów przetwórczych/technologicznych. 
Stosowane technologie przetwórstwa mięsnego mogą powodować zmiany struktur tkankowych i denaturację białek oraz degradację DNA w produktach wysoko przetworzonych. Poważnym wyzwaniem jest zatem identyfikacja autentyczności użytych surowców. Nadmienić należy, że produkty mięsne wysoko przetworzone są bardziej podatne na próby fałszowania i oszustwa. Zostało to wielokrotnie potwierdzone w badaniach, które wskazywały na większy odsetek produktów niezgodnych z deklaracjami producentów wśród grupy gotowanych produktów mięsnych w stosunku do surowego mięsa $[1,26]$. Wysoko przetworzone produkty bardzo często mają złożony skład surowcowy, zawierający czasami kilka gatunków mięsa w różnych proporcjach, składniki roślinne oraz cały szereg substancji dodatkowych, niezbędnych w procesie przetwórczym. Taki układ może sprzyjać ukryciu niektórych surowców mięsnych, [13, 26].

Ze względu na niszowość oraz stosunkowo wysoką cenę produktów ze strusia podjęto badania, których celem było opracowanie wiarygodnej procedury identyfikacji tego surowca. Jako narzędzie wybrano szybki test molekularny z wykorzystaniem techniki real-time PCR z użyciem specyficznych gatunkowo starterów. Ponadto założono przetestowanie opracowanej procedury na dostępnych komercyjnie produktach zawierających we wskazanym przez producenta składzie mięso strusia.

\section{Material i metody badań}

Materiał doświadczalny stanowiły kiełbasy ze strusiny (wyroby modelowe) wykonane w warunkach kontrolowanych, zawierające określony udział [\%] mięsa strusia (tab. 1). Opracowaną procedurę przetestowano na produktach ze strusiny dostępnych w sprzedaży detalicznej. Były to: serdelki, frankfurterki, steki, mięso gulaszowe.

Tabela 1. Zawartość mięsa ze strusia w kiełbasach (wyrób modelowy)

Table 1. The content of ostrich meat in sausages (model product)

\begin{tabular}{||c|c|c||}
\hline $\begin{array}{c}\text { Rzeczywisty udział mięsa stru- } \\
\text { sia / Actual percentage content } \\
\text { of ostrich meat [\%] }\end{array}$ & $\begin{array}{c}\text { Oszacowana zawartość mięsa } \\
\text { strusia / Estimated percentage } \\
\text { content of ostrich meat [\%] }\end{array}$ & $\mathrm{Cp}+\mathrm{SD}$ \\
\hline 100 & 101 & $17,62 \pm 0,11$ \\
\hline 80 & 81 & $18,39 \pm 0,16$ \\
\hline 60 & 62 & $19,07 \pm 0,19$ \\
\hline 40 & 36 & $20,14 \pm 0,62$ \\
\hline 20 & 21 & $21,72 \pm 0,34$ \\
\hline 0 & 0,001 & $32,71 \pm 0,56$ \\
\hline
\end{tabular}

Objaśnienia / Explanatory notes:

$\mathrm{CP}$ - cykl progowy / crossing point (threshold cycle); SD - odchylenie standardowe / standard deviation; $\mathrm{n}=3$. 
Środki ostrożności

Ze względu na bardzo wysoką czułość używanych metod, w celu zapobieżenia przypadkowym kontaminacjom, analizy wykonywano zgodnie z zaleceniami zawartymi w instrukcji dotyczącej zapewnienia jakości w laboratoriach wykonujących analizy PCR próbek środowiskowych (quality assurancelquality control guidance for laboratories performing PCR analyses on environmental samples) [10], w instrukcji dotyczącej zapewnienia i kontroli jakości analiz real-time PCR (real-time PCR core facility quality assurance/quality control guidance for real-time PCR analysis) [31] oraz przy uwzględnieniu dobrej praktyki laboratoryjnej dotyczącej wykonywania testów molekularnych (good laboratory practice when performing molecular amplification assays) [18].

W celu kontroli jakości prowadzonych analiz molekularnych wprowadzono próbki kontrolne według PN-EN ISO 24276:2007 [19] i zaleceń Laboratorium Referencyjnego Unii Europejskiej dla białek zwierzęcych w paszach [11].

Izolacja materiału genetycznego

Jałowym jednorazowym skalpelem chirurgicznym pobierano materiał, z którego odważano próbkę o masie $20 \pm 0,2$ g. Przenoszono ją do jałowego moździerza i homogenizowano. $\mathrm{Z}$ tak przygotowanej próbki pobierano naważkę o masie $0,2 \pm 0,05 \mathrm{~g}$ i przenoszono ją do 2-mililitrowej probówki typu eppendorf. Następnie przeprowadzano izolację DNA, używając zestawu Genomic Mini AX (A\&A Biotechnology, Polska) zgodnie z załączonym do zestawu protokołem, modyfikując czas i temperaturę enzymatycznej lizy analizowanego materiału. Uzyskany osad DNA zawieszano w $50 \mu \mathrm{l}$ buforu TE. Uwodnione DNA umieszczano w temp. $4{ }^{\circ} \mathrm{C}$ na $24 \mathrm{~h}$, a następnie przechowywano w temp. $-32{ }^{\circ} \mathrm{C}$ do czasu właściwych analiz.

Określenie stężenia izolowanego DNA

W celu określenia ilości i czystości wyizolowanego materiału genetycznego wykonywano pomiar stężenia DNA metodą spektrofotometryczną za pomocą spektrofotometru NanoDrop 1000ND (Thermo Scientific, USA), ustalając stosunek wartości absorpcji $A_{260}$ do $A_{280}$. Wykonana analiza pomiaru absorbancji przy długości fal $\lambda$ [nm]: 230, 260 i 280 pozwoliła na określenie stężenie DNA i czystości białkowej oraz organicznej [29]. Do dalszych analiz przeznaczano próbki, w których ilość uzyskanego materiału genetycznego wynosiła $60 \div 300 \mathrm{ng} / \mu \mathrm{l}$, przy współczynniku $\mathrm{A}_{260 / 280} \mathrm{~W}$ przedziale $1,8 \div 1,95$.

Startery $i$ warunki reakcji real-time PCR

Startery stosowane do identyfikacji gatunkowej strusia zaprojektowano z wykorzystaniem sekwencji nukleotydów opublikowanych w GenBanku (http:// 
www.ncbi.nlm.nih.gov/Genbank/). W tym celu używano programu Primer 3 (http://biotools.umassmed.edu/bioapps/primer3_www.cgi). Po wstępnej analizie wybrano dwa startery (tab. 2).

Tabela 2. Startery specyficzne gatunkowo dla strusia

Table 2. Species specific (for ostrich) primers

\begin{tabular}{||c|c|c|c||}
\hline $\begin{array}{c}\text { Starter } \\
\text { Primers }\end{array}$ & $\begin{array}{c}\text { Sekwencja (5'-3') } \\
\text { Sequences (5'-3') }\end{array}$ & $\begin{array}{c}\text { Identyfikacja } \\
\text { (gatunek) } \\
\text { Target DNAs } \\
\text { (species) }\end{array}$ & $\begin{array}{c}\text { Wielkość amplikonu (pz) } \\
\text { Amplikons size (bp) }\end{array}$ \\
\hline $\begin{array}{c}\text { cytb_Sc_F } \\
\text { (forward) }\end{array}$ & 5'-CCATACATTACACAGCCGACA-3' & 193 \\
\cline { 1 - 2 } $\begin{array}{c}\text { cytb_Sc_R } \\
\text { (reverse) }\end{array}$ & 5'-CCGGTGTTTCAGGTTTCTTT-3' (struś) & cytb (ostrich) & \\
\hline
\end{tabular}

Przed przystąpieniem do dalszych prac laboratoryjnych sprawdzano specyficzność wybranej pary starterów w programie BLAST (http://blast.ncbi.nlm.nih.gov/ Blast.cgi). Ponadto specyficzność starterów sprawdzano, wykorzystując matryce DNA wieprzowego, wołowego, kurzego, kaczego i indyczego (fot. 1).

Identyfikację gatunkową mięsa strusia prowadzono techniką real-time PCR, używając platformy LightCycler ${ }^{\circledR} 480$ II (Roche, Szwajcaria). Reakcje prowadzono w polipropylenowych 96-dołkowych płytkach titracyjnych (LightCycler® 480 Multiwell plate 96, Roche, Szwajcaria), uszczelnionych przeźroczystym filmem (LightCycler® 480 Sealing Foil, Roche, Szwajcaria). Łańcuchową reakcję polimerazy w czasie rzeczywistym prowadzono $\mathrm{w}$ objętości $25 \mu \mathrm{l}$ mieszaniny reakcyjnej zawierającej specyficzne startery, wyizolowany kwas nukleinowy o określonym stężeniu (50 ng/ $\mu \mathrm{l})$, LightCycler®480 SYBR Green I Master oraz wodę (water, PCR-grade). Do każdego eksperymentu dołączana była kontrola negatywna (NTC - no template control). W celu wykonania kontroli negatywnej zastępowano matrycę DNA wodą wolną od RNAz i DNAz.

Doświadczalnie ustalono następujące warunki reakcji: 1 cykl (pre-PCR dekontaminacja) - 5 min w temp. $95^{\circ} \mathrm{C}, 1$ cykl (pre-PCR denaturacja) - 10 min w temp. $95^{\circ} \mathrm{C}$ i 35 cykli po $30 \mathrm{~s} \mathrm{w}$ temp. $\left[{ }^{\circ} \mathrm{C}\right]: 95,51$ i 72. Reakcję kończyło 5-minutowe chłodzenie próbki. Każdą reakcję PCR prowadzono w trzech powtórzeniach (rys. 1), a dane analizowano za pomocą oprogramowania LightCycler® 480 Software ver. 1.5. 


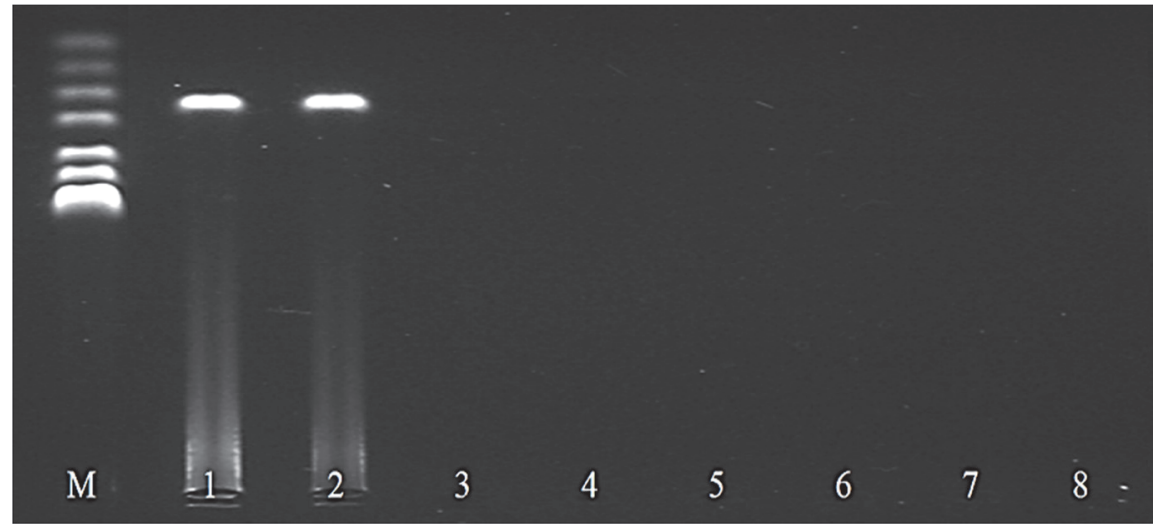

Objaśnienia / Explanatory notes:

Ścieżki / Tracks: M - wzorzec masowy / molecular marker (DNA Marker pUC/MspI); 1 - DNA strusia (kontrola dodatnia) / DNA of ostrich (positive control); 2 - DNA strusia (wyizolowane z produktu - serdelki ze strusia) / DNA of ostrich (isolated from product - ostrich sausages); 3 - DNA wieprzowe / pork DNA; 4 - DNA wołowe / beef DNA; 5 - DNA kurze / chicken DNA; 6 - DNA kacze / duck DNA; 7 DNA indycze / turkey DNA; 8 - NTC (no template control - kontrola ujemna) / NTC (no template control - negative control).

Fot. 1. Elektroforegram przedstawiający wynik reakcji PCR sprawdzającej specyficzność zaprojektowanych starterów

Photo 1. Electrophoregram displaying results of PCR reaction to check the specificity of primers developed

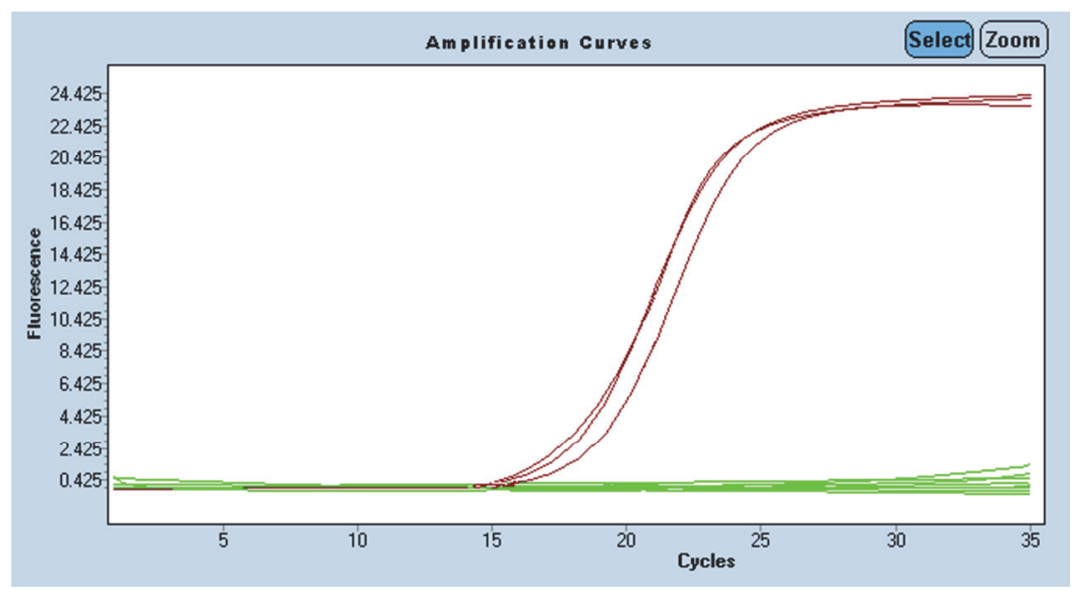

Rys. 1. Wynik identyfikacji obecności mięsa strusia techniką real-time PCR

Fig. 1. Result of ostrich meat presence identification performed using real-time PCR technique 
Przyjęta technika real-time PCR pozwala na analizę zarówno jakościową (identyfikacja gatunku), jak i ilościową (procentowa zawartość danego składnika) użytych surowców.

Do analizy ilościowego oszacowania zawartości mięsa strusia w przetworzonych produktach mięsnych utworzono krzywą kalibracji i znormalizowano wartości przy zastosowaniu cyklu progowego $(\mathrm{Cp})$ otrzymanego w reakcji amplifikacji DNA strusia i DNA eukariotycznego. Wartość Cp otrzymano w wyniku analizy 10 ng DNA. Krzywa kalibracji została skonstruowana przy użyciu próbek zawierających znane stężenia mięsa strusia [\%]: 100, 50, 25, 5, 1 i 0,1. Tak opracowaną procedurę przetestowano następnie na wyrobach modelowych wykonanych w warunkach laboratoryjnych w Katedrze Technologii Mięsa ZUT w Szczecinie.

\section{Wyniki i dyskusja}

Stwierdzono, że uzyskany wynik identyfikacji zawartości mięsa strusia był porównywalny z ilością surowca użytego do produkcji wyrobów modelowych (tab. 1).

W kolejnym etapie analizie poddano dostępne na lokalnym rynku produkty: frankfurterki, serdelki, stek i mięso gulaszowe, których producent deklarował na etykiecie, że jedynym składnikiem mięsnym było mięso strusia. W przypadku frankfurterek ze strusiny zawartość mięsa strusiego oznaczono na poziomie $70 \%$, a ponadto zidentyfikowano ok. $20 \%$ niewykazanego w składzie surowca wołowego i poniżej $1 \%$ - surowca wieprzowego. W przypadku serdelków również zidentyfikowano wołowinę (ok. $5 \%$ ) i wieprzowinę (ok. $17 \%$ ), natomiast strusina w tym produkcie stanowiła ok. $62 \%$. W pozostałych dwóch produktach (stek i mięso gulaszowe) jedynym surowcem mięsnym było mięso strusia.

Niestety zbyt mały asortyment produktów ze strusiny dostępnych na rynku nie pozwala na sformułowanie ogólnych wniosków, natomiast w tych jednostkowych przypadkach można przypuszczać nieświadome działanie producenta (ferma wraz z niewielkim zakładem przetwórstwa mięsa) lub świadome oszukiwanie konsumentów poprzez zastąpienie delikatesowej strusiny mięsem wołowym i wieprzowym albo niestaranność w etykietowaniu produktu i niewskazanie wszystkich użytych surowców.

Jak wykazano we wcześniejszych badaniach własnych [26], dość często zdarza się identyfikacja zanieczyszczenia obcym gatunkiem spowodowana przez niewystarczające czyszczenia urządzeń, zwłaszcza jeżeli produkty zawierające mięso z różnych gatunków zwierząt są wytwarzane w tym samym zakładzie.

Dotychczas wielu autorów opisywało rozwój czułych i wszechstronnych metod identyfikacji i analizy składu produktów mięsnych $[6,8,12,21]$, wykorzystując informacje uzyskane głównie na podstawie przeprowadzonych badań eksperymentalnych mieszanki surowców lub próbek poddanych obróbce cieplnej. Należy jednak zauważyć, że w przypadku mięsa strusia możliwości fałszowania są największe w produk- 
tach, w których wykorzystywane są różne rodzaje obróbki technologicznej oraz stosowane są różne składniki. W produktach tych pierwotna postać oraz tekstura mięsa ulega zmianie ze względu na przetwarzanie i mieszanie z innymi gatunkami mięs. Rojas i wsp. [23] podjęli próbę analizy w reakcji PCR w czasie rzeczywistym za pomocą układu sond molekularnych TaqMan ${ }^{\circledR} 100$ komercyjnych produktów mięsnych, do których produkcji wykorzystywany był surowiec strusi. Autorzy uwzględnili wpływ wielu różnych procesów technologicznych, takich jak: rozdrabnianie, gotowanie, suszenie, i sterylizacja. Ponadto w przypadku próbek mięsa zawierających więcej niż jeden gatunek (mięso z kurcząt, kaczek, bydła, świń) określono obecność poszczególnych gatunków. W większości przypadków otrzymane wyniki były zgodne z deklaracjami wymienionymi na etykietach. Jednakże kiełbasy suszone, które miały zawierać tylko mięso strusia, zawierały niedeklarowane DNA wieprzowe. Wyniki te mogą wskazywać na dodawanie do tych produktów tańszego i łatwiej dostępnego mięsa wieprzowego. Jednocześnie cytowani autorzy w konkluzji opisują, że uzyskane przez nich wyniki wskazują, że przyjęta metodyka może być stosowana przez instytucje odpowiedzialne za nadzór nad bezpieczeństwem żywności w celu rutynowej kontroli identyfikacji mięsa strusia oraz egzekwowania przepisów dotyczących etykietowania produktów mięsnych ze strusia.

Podobną technikę bazującą na systemie sond TaqMan ${ }^{\circledR}$ (również reakcja realtime PCR) w identyfikacji mięsa strusia opisali López-Andreo i wsp. [17]. Porównali oni dane doświadczalne z deklarowaną zawartością próbek testowych i wykazali, że zarówno absolutna ilość DNA, jak i względna zawartość poszczególnych gatunków (surowców) może być skutecznie zmierzona przyjętą techniką. Jednocześnie potwierdzili, że dobrą identyfikację uzyskuje się w przypadku udziału danego gatunku w ilości powyżej $10 \%$ masy produktu. Zawartość danego surowca w zakresie $5 \div 10 \%$ również można ilościowo oszacować, ale już z dokładnością do $80 \%$. Jeżeli natomiast udział danego gatunku jest mniejszy niż $5 \%$, to analiza ilościowa może być utrudniona. Mimo to przyjęty sposób detekcji może pomóc odróżnić nieuniknione zanieczyszczenia od celowego mieszania różnych składników.

Technikę real-time PCR jako narzędzie pozwalające zidentyfikować z jednej strony autentyczność pochodzenia surowca mięsnego, z drugiej zaś wykryć niepoprawne znakowanie zaproponowała Komisja Europejska w 2013 roku w związku z procederem fałszowaniem mięsa wołowego przez dodawanie do niego koniny. W ramach tych analiz Sawicki [25] wykazał przypadki występowania niedeklarowanego mięsa końskiego w produktach dostępnym na rynku krajowym, jak również przydatność techniki real-time PCR do analiz produktów o różnym stopniu przetworzenia. 


\section{Wnioski}

1. Przedstawiona w niniejszej pracy metoda wykorzystująca technikę PCR w czasie rzeczywistym charakteryzuje się wysoką czułością i swoistością. Może więc służyć jako skuteczna metoda identyfikacji i ilościowego oznaczania mięsa strusiego w różnych produktach mięsnych.

2. Zaproponowany sposób postępowania może ułatwić pracę związaną z identyfikacją autentyczności surowca strusiego w produktach mięsnych.

\section{Literatura}

[1] Abbas O., Zadravec M., Baeten V., Mikuš T., Lešić T., Vulić A., Prpić J., Jemeršić L., Pleadin J.: Analytical methods used for the authentication of food of animal origin. Food Chem., 2018, 246, 617.

[2] Adamczak L., Florowski T., Chmiel M., Pietrzak D.: Wydajność rzeźna strusi i uzysk wybranych elementów kulinarnych. Zesz. Probl. Post. Nauk Rol., 2013, 575, 3-11.

[3] Adamski M., Kuźniacka J., Milczewska N.: References of consumers for choosing poultry meat. Pol. J. Natur. Sci., 2017, 32, (2), 261-271.

[4] Bórawski P., Lewczuk A.: Wykorzystanie modeli logitowych do oceny dodatkowych i alternatywnych źródeł dochodów gospodarstw rolnych. J. Agribus. Rural Dev., 2009, 3 (13), 33-39.

[5] Cloete S.W., Brand T.S., Hoffman L.C., Brand Z., Engelbrecht A., Bonato M., Glatz P.C., Malecki I.A.: The development of ratite production through continued research. World's Poultry Sci. J., 2012, 68 (2), 323-334.

[6] Cottenet G., Sonnard V., Blancpain C., Ho H.Z., Leong H.L., Chuah P.F.: A DNA macro-array to simultaneously identify 32 meat species in food samples. Food Control, 2016, 67, 135-143.

[7] Dandage K., Badia-Melis R., Ruiz-García L.: Indian perspective in food traceability: A review. Food Control, 2017, 71 (1), 217-227.

[8] Doosti A., Ghasemi Dehkordi P., Rahimi E.: Molecular assay to fraud identification of meat products. J. Food Sci. Technol., 2014, 51 (1), 148-152.

[9] Dybowski G.: Produkcja. Rynek drobiu i jaj, 2018, 54, 8-11.

[10] EPA: Quality Assurance/Quality Control Guidance for Laboratories Performing PCR Analyses on Environmental Samples. U.S. Environmental Protection Agency, Cincinnati 2004.

[11] EURL-AP.: Method of reference for the detection of animal proteins in feed [on line]. Dostęp w Internecie [3.10.2018]: http://eurl.craw.eu/index.php?page=187

[12] Floren C., Wiedemann I., Brenig B., Schütz E., Beck J.: Species identification and quantification in meat and meat products using droplet digital PCR (ddPCR). Food Chem., 2015, 173, 1054-1058.

[13] López M.C.G., Alegre M.L.M.: Detection of adulterations: Addition of foreign proteins. In: Safety Analysis of Foods of Animal Origin. Eds. L.M.L. Nollet and F. Toldra. CRC Press, Boca Raton 2011, pp. 155-185.

[14] Horbańczuk J.O., Bielański P., Ligaszewski M.: Wykorzystanie niektórych gatunków zwierząt w rolniczej produkcji niszowej. Wiadomości Zoot., 2009, 47 (1), 37-43.

[15] Horbańczuk O.K., Wierzbicka A.: Technological and nutritional properties of ostrich, emu, and rhea meat quality. J. Veter. Res., 2016, 60, 279-286.

[16] Horbańczuk J.O., Tomasik C., Cooper R.G.: Ostrich farming in Poland - Its history and current situation after accession to the European Union. Poult. Avian Biol. Rev., 2008, 1, 65-71. 
[17] López-Andreo M.J., Lugo L., Garrido-Pertierra A., Prieto M.I., Puyet A.: Identification and quantitation of species in complex DNA mixtures by real-time polymerase chain reaction. Anal. Biochem., 2005, 339 (1), 73-82.

[18] Public Health England: Good Laboratory Practice When Performing Molecular Amplification Assays. Standards Unit, Microbiology Services, London 2013.

[19] PN-EN ISO 24276:2007. Artykuły żywnościowe. Metody wykrywania organizmów zmodyfikowanych genetycznie i produktów pochodnych. Wymagania ogólne i definicje.

[20] Poławska E., Cooper R.G., Jóźwik A., Pomianowski J.: Meat from alternative species - nutritive and dietetic value, and its benefit for human health - a review. CyTA - J. Food, 2013, 11, (1), 37-42.

[21] Qin P., Hong Y., Kim H.-Y.: Multiplex-PCR assay for simultaneous identification of lamb, beef and duck in raw and heat-treated meat mixtures. J. Food Safety, 2016, 36 (3), 367-374.

[22] Rogberg-Muñoz A.: Technologies in meat traceability, authenticity and safety. Recent Pat. Food Nutr. Agric., 2013, 5 (1), 2.

[23] Rojas M., González I., Pavón M.Á., Pegels N., Hernández P.E., García T., Rosario M.: Application of a real-time PCR assay for the detection of ostrich (Struthio camelus) mislabelling in meat products from the retail market. Food Control, 2011, 22 (3-4), 523-531.

[24] Sawicki W.: Autentyczność jako wyznacznik bezpieczeństwa żywności. W: Żywność dla przyszłości. Monografia CCIV. Red. A. Pęksa. Wyd. Uniwersytetu Przyrodniczego we Wrocławiu, Wrocław 2017, ss 475-482.

[25] Sawicki W.: Identification of horse meat in food products in the Polish market. Towar. Prob. Jak. 2017, 51 (2), 58-66.

[26] Sawicki W.: Techniki molekularne w analizie zafałszowań żywności. Wyd. Uczelniane Zachodniopomorskiego Uniwersytetu Technologicznego, Szczecin 2016.

[27] Sawicki W.: Wykrywanie niewłaściwych surowców w produktach spożywczych przy zastosowaniu techniki łańcuchowej reakcji polimerazy (PCR). Rozprawa doktorska. Akademia Rolnicza w Szczecinie, Szczecin 2006.

[28] Schwägele F.: Traceability from a European perspective. Meat Sci., 2005, 71 (1), 164-173.

[29] Słomski R.: Analiza DNA - teoria i praktyka. Wyd. UP w Poznaniu, Poznań 2008.

[30] Smith G.C., Tatum D.J., Belk K.E., Scanga J.A., Grandin T., Sofos J.N.: Traceability from a US perspective. Meat Sci., 2005, 71, (1), 174-193.

[31] UC Davis.: Real-time PCR Core Facility Quality Assurance/Quality Control Guidance for Real-time PCR Analysis. University of California, Davis 2011.

[32] Verrez-Bagnis V.: Detection of adulterations: Addition of foreign proteins. In: Handbook of Seafood and Seafood Products Analysis. Eds. L.M.L. Nollet and F. Toldra. CRC Press, Boca Raton 2009, pp. 603-614.

[33] Walter J.M., Soliah L.A., Dorsett D.: Ground ostrich: A comparison with ground beef. J. Am. Diet. Assoc., 2000, 100 (2), 244-245.

\section{THE PCR METHOD IN THE ASSESSMENT AUTHENTICITY OF MEAT PRODUCTS FROM OSTRICH (STRUTHIO CAMELUS)}

\section{$\mathrm{S} u \mathrm{~mm}$ a r y}

The proper labeling of food products that allows consumer making conscious purchase decisions regarding meat products is significant from many perspectives beginning from the health concerns and ending in religious aspects. Due to price differences and the availability of meat raw materials from different animal species, there are cases where the ingredients of meat products are not used adequately to the 
information given on the label. Non-compliances concern both the raw materials used and their content in the product, high-quality meat is replaced with cheaper or its content is less than declared. Despite binding regulations concerning the labeling of processed meat products, some cases of wrongly labeled meat products do occur on the market. This study was focused on developing a procedure for the verification of authenticity of meat products (sausages, steak, goulash) made of common ostrich (Struthio camelus) purchased in retail stores. A method using the real-time PCR technique was proposed. Research has shown that DNA is stable enough to withstand a variety of technological treatments. Meat samples were analyzed for the presence of common types of meat (pork as well as chicken, duck and goose meat) using speciesspecific starters. Results of these analyses demonstrated that the developed procedure of ostrich meat identification may be successfully applied for routine controls regarding both the quality (exclusion of a given species) and quantity (determination of percentage content of ostrich meat) of food products of this type. In addition the study demonstrated the likely problem of undeclared addition of meat not indicated on product labels of processed meat products.

Key words: ostrich meat, identification, food adulterations, real-time PCR 